\title{
Arctic lake promises hot data on past climate
}

Quirin Schiermeier, Munich

A preliminary excursion to a remote Russian lake has raised scientists' hopes that it will offer the most reliable terrestrial records yet of arctic climate history.

Located in the extreme northeastern tip of Siberia, Lake El'gygytgyn is unique, climate researchers say. Unlike most of the Arctic, the lake has never been covered by glaciers, which disrupt the accumulation of sediment. This means that El'gygytgyn's floor offers an uninterrupted view of past climate patterns.

"Drilling cores from the lake should provide a fantastic climate archive," says Thomas Stocker, a climate researcher at the University of Bern in Switzerland. "It would be a valuable supplement to marine drillings, whose information is always filtered by the ocean."

During a four-month expedition last year, geologists and limnologists from Germany, Russia and the United States probed the lake's sediments and surrounding permafrost soil to check out their likely usefulness. And at a meeting in Leipzig, Germany, late last month, they announced that their study had confirmed the lake's potential.

"Our survey has revealed that the bedding of the lake floor sediments is perfectly undisturbed," says Marin Melles, a geologist at the University of Leipzig and member of the expedition.

The lake is now being put forward as a site for the International Continental Drilling Program, a collaboration of 11 countries that aims to extract cores from the continental shelf, which would conduct a 400-metre deep-drilling project there in 2007.

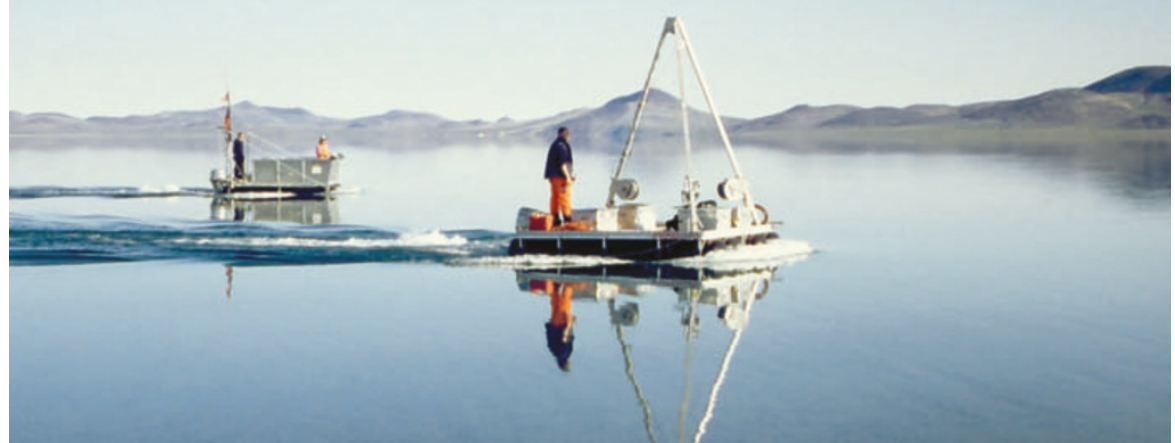

Icy yield: drilling at Lake El'gygytgyn has already retrieved a climate record for the past 400,000 years.

El'gygytgyn, which is about 175 metres deep and 15 kilometres across, fills the larger part of a crater created by a meteorite impact 3.6 million years ago. It is on the Chukotka peninsula, opposite Alaska, an area far from any settlement and very difficult to reach.

The expedition team and nine tonnes of equipment were flown to the lake last April by helicopter from Pevek, a small town on the East Siberian Sea.

Getting to the lake was difficult, Melles says. At first, Russian customs in St Petersburg declined to clear several items, including a snowmobile, which never made its way east. And summer evacuation from the camp, which was beginning to drown in seasonal mud, was delayed for a few days because available Russian helicopter pilots had hit statutory limits on their monthly flying hours. To get out, the researchers eventually had to hire a helicopter from a local gold-mining company.
But the scientific yield was worth the effort, says Julie Brigham-Grette, a geologist at the University of Massachusetts in Amherst. Brigham-Grette, in collaboration with Melles and with researchers at the North-East Interdisciplinary Scientific Research Institute in Magadan in far-eastern Russia, is analysing mineralogy and organic traces in the lake-floor sediments.

Seismic profiling shows that the sediments are some 400 metres thick, and probably contain an exceptional record running from the meteorite impact, in the Pliocene warm period, up to the present day. The expedition recovered a drilling core 16 metres long, representing the past 400,000 years, from the centre of the lake.

Deep drilling in Lake El'gygytgyn would help researchers study arctic climate change before the onset of glaciation 2.2 million years ago, explains Brigham-Grette.

www.icdp-online.de/welcome.html

\section{Queen flies the flag for cancer alliance at Paris bash}

Declan Butler, Paris

Queen Elizabeth II was in

Paris last week to mark a century of Anglo-French accord. And as part of the celebrations she found herself rubbing shoulders with top cancer researchers from both sides of the Channel.

A sumptuous dinner at the British Embassy in Paris saw the Queen, her husband Prince Philip and Bernadette Chirac, wife of French

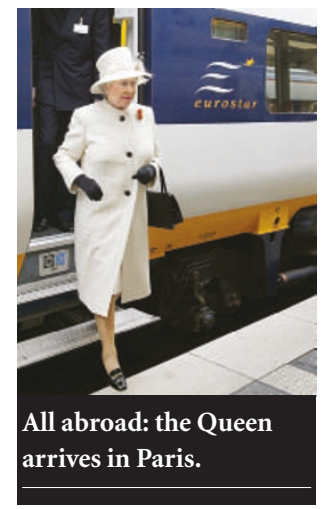

On the menu, apart from a 1985 Château Margaux, was cooperation on cancer. British figureheads such as Colin Blakemore, head of the Medical Research Council, Mark Walport, chief executive of the Wellcome Trust, and Liam O'Toole, director of the National Cancer Research Institute, met the leaders of France's top cancer centres, such as Daniel Louvard, director of the Curie Institute, and Thomas Tursz, president Jacques Chirac, assuming the role of matchmakers to bring scientists from the two countries closer together. The event was held to celebrate the centenary of the entente cordiale, an agreement signed on 8 April 1904 to end the countries' colonial disputes. director of the Gustave Roussy Institute.

John Holmes, the British ambassador in Paris, announced a $€ 600,000$ (US\$730,000) scheme, funded equally by Britain and France, to support the best young cancer researchers from both countries. And the Princess Zahra
Aga Khan, daughter of businessman the Aga Khan and coordinator of the health services arm of the Aga Khan Development Network, agreed to fund an Entente Cordiale Cancer Research Prize to reward one up-and-coming researcher from each country.

Cancer leaders at the event said that both countries could benefit from collaboration in everything from bioinformatics to tissue banks. Their information is currently held in different languages, on incompatible computer systems.

Researchers also agreed to a joint conference this autumn on bioethics - an area where Britain's utilitarian outlook is sharply at odds with the more philosophical French position (see Nature 389, 661-662; 1997). The two countries will organize rock concerts, operas and sporting events this year to fund their cancer-research plans. 